\title{
Child health and ionizing radiation: Science, Politics and European Law
}

\author{
Christopher Busby* \\ Environmental Research SIA, Latvia
}

\section{Commentary}

Between 2000 and 2006 the European Union funded a panEuropean group of epidemiologists, toxicologists and paediatricians, the Policy Information Network on Child Health and Environment (PINCHE) [1]. The purpose of the network was to examine all the literature on environmental contamination agents to provide evidencebased recommendations to the European Commission on how best to regulate exposures that had been shown or suspected to affect childrens' health. The need for this was apparent from the increasing incidence of a number of illnesses in children and young people like childhood cancer, leukemia, asthma and a range of other increasingly prevalent conditions. Additionally, one purpose was to recommend ways in which the Commission could set up agencies or committees to develop ways in which causal linkages between exposure and illnesses might obtain unbiased information. This workgroup was the SciencePolicy interface, and I was the leader of this group. PINCHE reported in 2006 and its recommendations were published in the literature [2-4] are available on the web.

One important recommendation of PINCHE followed from its realization that scientific advice to policy-makers was clearly biased by the make-up of expert committees, by scientific lobbyists, and indeed by the bias in funding of research into environmental exposure issues. The development of legal constraints in Europe on exposures to trichloroethylene discussed by Ruden [5] was cited as one an example of bias introduced by scientists working for the chemical industry.

One of the areas of discussion was ionizing radiation, and the final report on this in 2006 was also published separately [6]. It drew attention to the increasing evidence then that the radiation risk model that was the basis of European Law, a model developed by the International Commission on Radiological Protection (ICRP) [7] was unsafe for predicting or explaining effects of internal radiation exposures in children. Evidence for adverse health effects in children began with the discovery of excess child leukemia rates near the radioactive fuel reprocessing plant at Sellafield in the UK, but by 2006 , such excess risk had been identified in epidemiological studies of several other radioactively contaminated nuclear sites in the UK, France and Germany [8-11]. The response of government advisory committees and those scientists designated in EU Member States to consider such information had entirely been to dismiss causation [12]. This dismissal was made on the basis that the absorbed doses received by the children or their parents was far too low to cause any effect.

The possibility that internal exposures to novel radionuclides might represent a genetic or genomic hazard not adequately addressed by the conventional ICRP model had been raised by the European
Committee on Radiation Risk (ECRR), an independent group of scientists and experts formed in Brussels in 1998, in a report published in 2003 [13]. Additionally, the UK Departments of Health and Department of the Environment had jointly set up the Committee Examining Radiation Risk from Internal Emitters (CERRIE) in 2001. CERRIE was unsuccessful in its remit. The Environment Minister Michael Meacher was removed by the Prime Minister Tony Blair in 2004 and the committee wound up. There were two reports, the official one [14] and a Minority Report [15]. But overall, the committee agreed and reported that for certain kinds of internal exposures, the concept of Absorbed Dose, used to quantify biological effects of exposure was meaningless. If this were so, then clearly the excess child leukemia in groups exposed to internal radionuclides could be causal, since what I will term the genetic dose would be very much higher than the calculated absorbed dose. This genetic dose concept was developed by the ECRR in its reports in 2003 and 2010 [13,16], though the quantity developed by ECRR had not been named then. The unit Müller (Mü) for Genetic Dose was recently suggested by the sub-committee on Units and Measurements of the International Foundation on Research on Radioactivity Risk in Stockholm in 2016 and will be adopted in 2017 by the ECRR main committee. Herman Müller was the Nobel Prize winning discoverer of the genetic effects of ionizing radiation and warned in 1950-52 (contentiously at the time, though accurately, as it turned out) of the serious genetic damage that atmospheric atomic testing would introduce to the human race. Absorbed doses are, in the ECRR model, multiplied by hazard enhancement factors based on the chemical nature and other attributes of the internal exposures. The issue is one of radiochemical genotoxicity $[13,16]$.

The relationship between exposure, quantified as Absorbed Dose (Grays, Sieverts, Rads Rems) is historically tied to the cancer and genetic effects measured in the study of the survivors of the Atomic bombing of Hiroshima and Nagasaki in 1945. In this Life Span Study (LSS), groups of individuals were recruited in 1952 (some 7 years after the bombing) and their cancer and any heritable effects in children recorded and related to the estimated Absorbed Doses they received. The dose estimates were based on calculations relating to the individual's distance from the hypocentre of the detonation and experiments made on similar bombs exploded in the Nevada Desert in the USA. The risk coefficients derived from this study, which is on-going, are provided by the ICRP and form the basis of legal constraints on exposure. However,

Correspondence to: Christopher Busby, Environmental Research SIA, 1117 Latvian Academy of Sciences, Riga LV-1050, Latvia, E-mail: christo@greenaudit.org Received: July 20, 2017; Accepted: August 12, 2017; Published: August 14, 2017 
the LSS doses are all external doses, and do not include any estimate of internal exposures to fallout and rainout from the bomb components which contaminated the areas where all the high, medium and low dose groups were situated. In addition, there was a no-dose group, the Not in City group who came to the towns some months after the bombs and who lived in the fallout contaminated areas. The principal internal exposures were to Uranium and Plutonium components of the weapons themselves.

The issue of the total failure of the LSS to deal with internal exposures was raised recently in an invited letter to the Journal Genetics [17], where it was argued that since the LSS was silent on the heritable effects of internal exposures, other studies were needed to determine these risks.

How could such risks be determined? What evidence could be employed to formulate accurate risk coefficients? What effect should such risk coefficients have on legal limits and on the societal regulations? The Chernobyl accident in 1986 represented a very important event with regard to examining the heritable and other effects of exposures to internal fission-product and Uranium contamination of environments [18]. In 2017 it is now clear that following from Chernobyl, a large number of epidemiological studies of heritable effects in contaminated areas of Europe and of countries as far away as Egypt and Turkey reported significant increases in almost all congenital malformations, genetic defects and heritable conditions including infant leukemia. These results in newborn babies and children are also pointers to effects in later life, since, it is now universally accepted that cancer and a wide range of adverse health effects follow from genetic and genomic damage. A 2016 review of the heritable effects of exposures to internal fission-product contamination, which majored on Chernobyl effects, showed clearly that internal exposures to as low as $1 \mathrm{mSv}$ (calculated as Absorbed Dose) could cause significant observable excess risks in babies and children [19]. Reference was made to some 20 or more studies published in the peer-review literature by different groups of researchers in different countries. The risk coefficient derived from these combined studies gave a doubling dose for heritable effects of at least $10 \mathrm{mSv}$, and the analysis showed clearly that the dose-response was non-linear, for reasons given in the paper. The ICRP's doubling dose for heritable effects of around $1000 \mathrm{mSv}$ or more, was derived from mice because the LSS apparently did not show any heritable effects in humans. Reasons for this error were discussed in the 2016 review [19].

The radiobiological explanation of such findings, and evidence from theoretical and experimental studies had been already published in a review of internal exposures in 2013 [20]. Essentially this explanation involved examining the ionization at the target, cellular DNA and comparing this with the mean ionization over large tissue volumes. The most hazardous internal exposures were predicted to be from radionuclides with chemical affinity for DNA, principally Strontium-90 and Uranium, which latter exists as the Uranyl ion $\mathrm{UO} 2++$ and binds strongly to DNA. Thus it is the genetic dose of the ECRR that is the correct measure of such genetic damage.

Armed with this evidence from Chernobyl, it is possible to go back and re-examine all the examples of internal exposures, from the cold war atmospheric testing, the nuclear site childhood cancers [21-25], a range of studies of groups living near individual nuclear sites, and those exposed to Uranium [26-28]. All these represent evidence that the ICRP and current radiation risk models, upon which legal limits are based, have got it very wrong indeed, and that as a consequence, as the PINCHE report suggested, and the ECRR reports state, radionuclide contamination of the biosphere has had quite alarming effects.

However, the purpose of this Commentary is not to persuade the scientific community about this but rather to ask how these pieces of evidence can bring about a change in the law. Black Letter Law in Europe provides for such a possible change in scientific knowledge, and was set up in 1996 to accommodate possible changes in scientific models. Changes in scientific viewpoints have occurred throughout history of course, so it would have been remiss not to build into the laws a mechanism for dealing with new evidence. However, as I shall show below, the inertia and control of those who administer the laws on radiation protection, and perhaps also the economic and military pressures on the administrators have so far made it impossible to trigger the legal system of protection. Shortly and crudely put: how can members of the public and scientists stop releases of radioactivity which we now have the evidence to demonstrate unequivocally routinely kill babies and cause epidemics of cancer and other ill health in those who are supposedly protected by an incorrect radiation model?

The Law in Europe is the EURATOM 96/29 Basic Safety Standards Directive of $13^{\text {th }}$ May 1996, transposed into all EU Member States by May 2000.The Directive is thus Law in each member state. The Directive accepts that there are harmful effects of exposures but states clearly that any such exposures have to be "Justified" In Article 6.2 it states:

Existing classes or types of practice may be reviewed as to Justification whenever new and important evidence about their efficacy or consequences is acquired.

Following enquiries of the European Commission made by UK Green Party European Parliamentarian Caroline Lucas in 2009 it was stated clearly that any requirement for re-Justifying radiation exposures must be carried out firstly in Member States where the laws were the responsibility of the EURATOM contact person in the State's National Competent Authority. From December 2016 individual citizens of the UK, the Republic of Ireland, Sweden, France, Germany and Denmark wrote to the legal EURATOM contact person in their country the following letter:

Justification of radiation exposures of members of the public and workers: review of existing practices.

New and important information.

\section{EURATOM CONTACT}

\section{National Competent Authority}

\section{State}

\section{Dear Sir/Madam,}

1. This request requires the re-justification of historic and currently on-going practices involving exposures of members of the public and workers to ionizing radiation principally from radionuclide contamination of the environment.

2. Under Article 6.2 of the Council Directive 96/29/Euratom of 13 May 1996:

Existing classes or types of practice may be reviewed as to Justification whenever new and important evidence about their efficacy or consequences is acquired

3. Under Article 19(2) of the Council Directive 2013/59 of $5^{\text {th }}$ Dec 2013:

Member States shall consider a review of existing classes or types of 
Table 1. Responses of the National Competent Authority EURATOM designated legal contact and also other State actors to requests from individuals in Member States to re-Justify radiation exposures under Article 6.2 of the EURATOM 96/29 Directive.

\begin{tabular}{|c|c|c|}
\hline EU State & Contact Person (s) & Result \\
\hline United Kingdom & $\begin{array}{l}\text { 1. EURATOM Justification Authority; contact: } \\
\text { 2. Health Protection England (HPE) } \\
\text { 3. COMARE }\end{array}$ & $\begin{array}{l}\text { Request sent in November 2016. Acknowledgement promised a response in March 2017. Response from } \\
\text { Matt Clarke of Department of Energy and Climate Change which stated that there was no new and important } \\
\text { evidence. Did not address the evidence supplied. Response was based on advice from HPE. } \\
\text { COMARE Chair Chris Gibson also did not address the evidence but rather referred to irrelevant and selective } \\
\text { reports dating from before 2005. A reply to this COMARE letter pointing out the deficit has not been responded to. }\end{array}$ \\
\hline $\begin{array}{l}\text { Republic of } \\
\text { Ireland }\end{array}$ & $\begin{array}{l}\text { 1. Contact Person National Contact Point: LEHANE } \\
\text { Michéal (Director) } \\
\text { 2. EPA/ORP (Environmental Protection Agency/ } \\
\text { Office of Radiological Protection) }\end{array}$ & $\begin{array}{l}\text { Letter was sent in Jan 2017. Measured response was made by Ciara McMahon agreeing that the area of internal } \\
\text { radiation effects was a legitimate concern but stated that not enough evidence had been available generally. } \\
\text { Referred to CERRIE. Did not refer to the evidence sent in terms of New and Important Evidence. A reply to } \\
\text { this asking for a specific response to the Chernobyl heritable effects evidence has not been responded to. }\end{array}$ \\
\hline Sweden & $\begin{array}{l}\text { 1.EURATOM contact: HASSEL Fredrik } \\
\text { 2. SSM } \\
\text { 3. Swedish Environment Ministry } \\
\text { 4. Swedish Justice Chancellor }\end{array}$ & $\begin{array}{l}\text { Initial refusal to address this was followed by a visit to the SSM in Stockholm. When finally cornered Hassel } \\
\text { wrote that it was not the responsibility of SSM or his personal responsibility to initiate any re-justification on } \\
\text { the basis of new and important evidence. Did not address the evidence. He stated that this matter was in the } \\
\text { responsibility of the ICRP. His refusal was reported in a letter to the Justice Chancellor and to the Swedish } \\
\text { Environment Ministry. A letter from the Environment Ministry stated that it has all confidence in the SSM. }\end{array}$ \\
\hline France & EURATOM contact & Initial reply stated that formal response would be made. 3 months later no response has been received. \\
\hline Denmark & EURATOM contact ØHLENSCHLAEGER Mette & $\begin{array}{l}\text { Both initial replies and responses to further letters stated that the issue is one for the ICRP and not for the } \\
\text { Danish National Competent Authority }\end{array}$ \\
\hline Germany & $\begin{array}{l}\text { 1. EURATOM contact } \\
\text { GREIPL Christian (Head of Directorate Radiological } \\
\text { Protection) } \\
\text { 2. BfS }\end{array}$ & No reply has been received. \\
\hline
\end{tabular}

${ }^{a}$ Committeeon Medical Aspects of Radiation in the Environment

${ }^{\mathrm{b}}$ Swedish Radiological Protection Authority

${ }^{\mathrm{c}}$ GermanRadiological Protection Authority.

practices with regard to their justification whenever there is new and important evidence about their efficacy or potential consequences.

The letter went on to outline the evidence reviewed above, in particular the increases in heritable effects in populations exposed to Chernobyl contamination outlined above and reviewed in the 2016 Schmitz-Feuerhake et al paper [18]. Some results of this exercise are listed in Table 1 below.

Now it is clear from the responses received from those individuals written to that they accept that they have to write something in reply: it is the law. But what is also clear is that they have no intention of carrying out any re-justification. The responses fall into two categories.

1. It is not the responsibility of the State to adjust the basis of radiation protection law if new scientific discoveries show that the law is unsafe and is not protecting the public. It is somehow the responsibility of the ICRP to do this.

2. It is the responsibility of the State to re-justify exposures on the basis of new and important evidence, but the relevant authorities will not address the evidence or will dismiss it by referring to other selective or irrelevant information.

Now response (1) above is just not true. The ICRP has no democratic authority whatever: it is a charity that advises on radiation risk, and in this it is little different from the ECRR. It is the National Competent Authority of the Member State that has to examine the new and important evidence and act on it. Some of the countries took this latter position but refused to act. It is now not my intention to argue here whether the evidence I have outlined is accurate or not. But it might have been possible for those individuals and agencies addressed to provide critical analysis of all the studies reviewed in SchmitzFeuerhake 2016, arguing, for example, that the studies were unsafe for whatever reason, or that they had been carried out badly, or that the data was suspect. But none of the EURATOM designated individuals and National Competent Authorities addressed the evidence at all. It is hard to see how they could have, given the number of studies and the wide degree of agreement between them in the many different countries where they were carried out. Thus it is clear to all that there is a distinct possibility, indeed probability, that the new evidence from Chernobyl (and from other studies reviewed in the Schmitz-Feuerhake et al 2016 review) indicates that as a result of perhaps understandable historical mistakes resulting from early science, the current radiation protection regime has allowed and continues to allow, serious genetic and genomic damage to the human population. What can be done to force the evidence of this into the political and legal domain?

\section{Conclusion: Ethical, philosophical and political dimensions}

It is clearly unacceptable for any Society to permit processes which create contamination that causes illness or death in its citizens. Nevertheless, there are many activities and processes which are of value to Society as a whole but which are known to cause harmful effects. Laws are then developed to balance such harm against advantages to Society as a whole. This process is based on the Utilitarian or costbenefit philosophy of Jeremy Bentham and John Stuart Mill. The issue, as it pertains to radiation protection is reviewed in ECRR2003 and ECRR2010 where injustices of utilitarianism and the alternative "human rights" approaches are discussed [13]. The ICRP specifically refers to a utilitarian approach in its publications [7] where it suggests that a death rate of one in 1 million exposed individuals may be considered acceptable to society. This is a clear Utilitarian decision, and (although the mathematical derivation is a matter of question) is the stated basis for an annual dose limit of $1 \mathrm{mSv}$, adopted by the EURATOM BSS also. However, it is clear that the new and important evidence provided by the Chernobyl heritable effects lead to a birth defect rate, and of course excess infant death rate which is or the order of $50 \%$ following an internal exposure of $1 \mathrm{mSv}$. Such exposures occur and have occurred in many scenarios; and infant deaths have also been recorded after such exposures. A very recent example is the study of infant mortality associated with exposure to Radium following gas well development (fracking)in Pennsylvania [29]. The history of science has 
been full of major changes in scientific models. But none of these, from Galileo, Newton, Einstein, etc. can have had quite the public health impact as the revelation that internal radionuclide exposures are so genotoxic and that the model employed to quantify these exposures is totally unsafe. Politicians and radiation risk agencies and experts are now caught between human health and economic (nuclear energy, fracking) and military (nuclear weapons, depleted uranium) projects which depend upon permitting radioactive contamination. And it seems that the public or well-meaning networks of independent experts like PINCHE are powerless change this or to trigger the legal processes available to stop it happening (Table 1).

\section{References}

1. van den Hazel P, Zuurbier M, Bistrup ML, Busby C, Fucic A, et al. (2006) Policy and science in children's health and environment: recommendations from the PINCHE project. Acta Paediatr Suppl 95: 114-119.[Crossref]

2. Busby C, Fucic A (2006) Ionizing radiation and children's health: conclusions. Acta Paediatr Suppl 95: 81-85.[Crossref]

3. Koppe JG, Bartonova A, Bolte G, Bistrup ML, Busby C, et al. (2006) Exposure to multiple environmental agents and their effects. Acta Paediatr Suppl 453 106-114. [Crossref]

4. Van den Hazel P, Zuurbier M, Babisch W, Bartonova A, Bistrup ML, et al. (2006) 'Today's epidemics in children: possible relations to environmental pollution'.Acta Paediatrica Suppl 453: 18-25.[Crossref]

5. Rudén C (2001) Interpretations of primary carcinogenicity data in 29 trichloroethylene risk assessments. Toxicology 169: 209-225.[Crossref]

6. Busby C, Fucic A (2006) Ionizing radiation and children's health: conclusions. Acto Paediatr Suppl 95: 81-85.[Crossref]

7. ICRP, International Commission on Radiological Protection (2007) The 2007 Recommendations of the International Commission on Radiological Protection. ICRPPublication 103, Ann ICRP 37. Oxford: Pergamon: 2-4.

8. Roman BE, Bobrow M(eds.) (1993) Childhood Cancer and Nuclear InstallationsLondon: British Medical Journal.

9. Independent Advisory Group (1984) Investigation of the Possible Increased Incidenceof Cancer in West Cumbria, The Black Report, (London: HMSO).

10. Kaatsch P, Spix C, Schulze-Rath R, Schmiedel S, Blettner M (2008) Leukaemia in young children living in the vicinity of German nuclear power plants. Int J Cancer 122 : 721-726.[Crossref]

11. Laurier D, Hemon D, Clavel J, (2008) Childhood leukaemia incidence below the age of 5 years near French nuclear power plants. J Radiol Prot 28: 401-403.[Crossref]

12. COMARE (1996) The Incidence of Cancer and Leukaemia in Young People in the Vicinity of the Sellafield Site in West Cumbria: Further Studies and Update since the Report of the Black Advisory Group in 1984, COMARE 4th Report (Wether by: Department of Health).

13. ECRR 2003 (2003) Recommendations of the European Committee on Radiation
Risk- The health effects of ionizing radiation at low dose--Regulator's (edn). Busby C, Bertell R, Yablokov A, Schmitz Feuerhake I, et al (edts). (Brussels: ECRR)

14. CERRIE (2004) Report of the Committee Examining Radiation Risk from Internal Emitters (CERRIE) Chilton, UK: National Radiological Protection Board

15. Busby CC, Bramhall R, Dorfman P (2004) CERRIE Minority Report 2004: Minority Report of the UK Department of Health/ Department of Environment (DEFRA) Committee Examining Radiation Risk from Internal Emitters (CERRIE) Aberystwyth: Sosiumi Press.

16. Busby C, Yablolov AV, Schmitz Feuerhake I, Bertell R, Scott Cato M (2010) ECRR2010 The 2010 Recommendations of the European Committee on Radiation Risk. The Health Effects of Ionizing Radiation at Low Doses and Low Dose Rates. Brussels: ECRR; Aberystwyth Green Audit.

17. Busby Christopher (2016) Letter to the Editor on "The Hiroshima Nagasaki survivor studies. Discrepancies between results and general perception.” By Bernard R Jordan. Genetics 204: 1627-1629.

18. Busby C, Lengfelder E, Pflugbeil S, Schmitz-Feuerhake I (2009) The evidence of radiation effects in embryos and fetuses exposed by Chernobyl fallout and the question of dose response. Med Confl Surviv 25: 18-39. [Crossref]

19. Schmitz-Feuerhake, Busby C, Pflugbeil P (2016) Genetic Radiation Risks-A Neglected Topic in the Low Dose Debate. Environ Health Toxicol 31: e2016001.[Crossref]

20. Busby Christopher (2013) Aspects of DNA Damage from Internal Radionuclides, New Research Directions in DNA Repair, Prof. Clark Chen (Ed.), ISBN: 978-953-511114-6, InTech, DOI: 10.5772/53942. [Available from: http://www.intechopen.com/ books/new-research-directions-in-dna-repair/aspects-of-dna-damage-from-internalradionuclides]

21. Whyte RK (1992) First Day Neonatal Mortality since 1935: A Re-examination of the Cross Hypothesis. BMJ 304: 343-6.[Crossref]

22. Busby C, de Messieres M (2014) Miscarriages and congenital conditions in offspring of the British Nuclear Atmospheric test Program. Epidemiology (Sunnyvale) 2014.

23. Busby CC (2009) Very Low Dose Fetal Exposure to Chernobyl Contamination Resulted in Increases in Infant Leukemia in Europe and Raises Questions about Current Radiation Risk Models. IntJ Environ Res Public Health 6: 3105-3114.[Crossref]

24. Busby C, de Messieres M, Saoirse M (2015) Infant and perinatal mortality and Stillbirths near Hinkley Point nuclear power station in Somerset, 1993-2005; an epidemiological investigation of causation. JJ Epidemiol Prevent 1: 013.

25. Busby C (2015) Editorial: Epidemiology and the Effects of Radioactive Contamination: Time for a New Approach. J J Epidemiol Prevent 1: 2.

26. Busby C (1994) Prostatic cancer and radionuclides. Excess of other cancers in Wales. BMJ 308: 268.[Crossref]

27. Busby C, de Messieres M, Saoirse M (2015) Infant and perinatal mortality and Stillbirths near Hinkley Point nuclear power station in Somerset, 1993-2005; an epidemiological investigation of causation. JJ Epidemiol Prevent 1: 013.

28. Busby C, Malak H, Ariabi E (2010) Cancer, Infant Mortality and Birth Sex-Ratio in Fallujah, Iraq 2005-2009. Int J Environ Res Public Health 7: 2828-2837.[Crossref]

29. Busby C, Joseph M (2017) There's a world going on underground-infant mortality and fracking in Pennsylvania. $J$ Environ Protect 8.

Copyright: (C2017 Busby C. This is an open-access article distributed under the terms of the Creative Commons Attribution License, which permits unrestricted use, distribution, and reproduction in any medium, provided the original author and source are credited. 